\title{
The 46th annual meeting of the European Society for Blood and Marrow Transplantation: lectures
}

C) Springer Nature Limited 2020

29 August - 1 September, 2020 Virtual Meeting

Copyright: Modified and published with permission from https://www.ebmt.org/annual-meeting

Sponsorship Statement: Publication of this supplement is sponsored by the European Society for Blood and Marrow Transplantation.

1998

Treating CML: present and future strategies

J. Goldman (London, UK)

1999

Role of transplantation in treatment of AML

A. Burnett (Cardiff, UK)

2000

The past, present and future of stem cells

B. Torok-Storb (Seattle, USA)

2001

Gene therapy of severe combined immunodeficiencies

A. Fischer (Paris, F)

2002

Aplastic anaemia: the missing stem cell - lessons for the future

E. Gordon-Smith (London, UK)

The created stem cell - therapeutic potential of animal cloning technologies
A. Colman (Edinburgh, UK)

2003

Graft versus host diseases: still a problem in $\mathbf{2 0 0 3}$

A. Bacigalupo (Genoa, I)

2004

SCT for CML in the imatinib era

J. Goldman (London, UK)

2005

The beneficence of cord blood cells

E. Gluckman (Paris, F)

2006

Arts lecture: the colours still glow - art and life of Emil Nolde

J. Garbrecht (Neukirchen, D)

2007

EBMT travels in the past and the future

J.-L. Touraine (Lyon, F) 
2008

Will haematopoietic stem cell transplantation cure human autoimmune diseases?

A. Marmont (Genoa, I)

2009

Cell therapy in multiple myeloma - facts and visions

G. Gahrton (Stockholm, S)

2010

Music and medicine

K. Laczika (Vienna, AT)

2011

The rise and fall of the dinosaurian empire

P. Taquert (Paris, FR)

2012

The viral genome within

D. Trono (Lausanne, $\mathrm{CH}$ )

2013

How transplantation antigens influenced human immunity, reproduction and evolution

P. Parham (Stanford, USA)

2014

Medicine as an art: Past and Present
G. Bordini (Parma, I)

2015

In 2015, look after your gut bugs

J. Dore (Paris, FR)

2016

Multiple Myeloma: Evolution in the treatment landscape

Jesus San Miguel (Pamplona, ES)

2017

60 years of HSCT: progress from bone marrow transplantation to the first cellular and gene therapies Rainer Storb (Seattle, USA)

2018

The CAR T Revolution

Stephan Grupp (Philadelphia, USA)

2019

Loss of Biodiversity

Volker Mosbrugger (Frankfurt, Germany)

2020

How the treatment is evolving in transplant-eligible newly diagnosed Multiple Myeloma?

María-Victoria Mateos Manteca (Salamanca, Spain) 